\title{
Joint Consultation and Workers Commitment in Nigerian Banking Industry
}

\author{
Tarela Okpu ${ }^{1} \&$ Seth Accra Jaja ${ }^{2}$ \\ ${ }^{1}$ Faculty of Management Sciences Niger Delta University, Nigeria \\ ${ }^{2}$ Faculty of Management Sciences Rivers State University of Science and Technology, Nigeria \\ Correspondence: Tarela Okpu, Niger Delta University, Amassoma, Bayelsa State, Nigeria. Tel: \\ 234-803-339-3660. E-mail: tarela21@yahoo.com \\ Received: October 18, $2013 \quad$ Accepted: January 31, $2014 \quad$ Online Published: February 21, 2014 \\ doi:10.5539/ijbm.v9n3p53 \\ URL: http://dx.doi.org/10.5539/ijbm.v9n3p53
}

\begin{abstract}
This study examined the relationship between Joint Consultation, a form of Employee Voice and Workers Commitment. Using Cross Sectional Survey design, a sample size of 357 workers from the banks in the South-South zone of Nigeria was used as respondents. The results drawn from the use of Spearman Rank Order Correlation showed that Joint Consultation had a significant positive association with workers affective commitment, but no significant association with workers continuance and normative commitment. The study found that with the use of Joint Consultation, workers are emotionally attached to their organizations and exhibits little continuance and normative commitment.
\end{abstract}

Keywords: joint consultation, affective commitment, normative commitment, continuance commitment, employee voice

\section{Introduction}

In order to gain competitive advantage, organizations must ensure that they have employees who are motivated and committed (Salami, 2008; Oladejo et al., 2011). Researchers (Ahiauzu \& Asawo 2012; Kimball \& Nink; 2006) report that commitment of workers in organizations continues to be a major problem for management practitioners. According to Nwachukwu (2006) employees usually show lack of commitment to organizations by engaging in negative behaviour such as absenteeism, complaints about organizational processes, not speaking up when issues are being addressed because of fear or lack of trust for senior managers and not owning up to their mistakes but rather shifting blame for failure to others. A study by Okpara (2004) revealed that Nigerian managers reported lower levels of commitment than their US counterparts. One of the reasons proffered for this was their lack of control over decision making and lack of representative voice. Allen and Meyer (1991) believe that a committed employee is more willing to exert extra effort and work towards organizational goals. Therefore it is very important for organizations to ensure that they get the commitment of their employees.

The importance of organizational commitment has been highlighted by several studies (Farndale et al., 2011; Ahiauzu \& Asawo, 2009; 2008; Gbadamosi, 2003; Zabid et al., 2003; Oladejo et al., 2011; Angle \& Perry, 1981; Salami, 2008). This has led to researches being carried out to investigate the impact of other constructs on organizational commitment. For instance Ahiauzu and Asawo (2009) studied the impact of altruistic love as an element in the emerging theme of workplace spirituality, and 'workers' commitment' in the Nigerian manufacturing industry. Ogba (2008) examined the impact of income and age on organizational commitment. Gbadamosi (2003) highlighted contemporary issues in organizational commitment as it relates to human resources management. Other constructs associated with organizational commitment are: performance (Zabid et al., 2003; Oladejo et al., 2011), Monetary rewards (Omolayo \& Owolabi, 2007), Effectiveness (Angle \& Perry, 1981), psychological and demographic factors (Salami, 2008), structure (Ardrey et al., 2001), withdrawal intentions (Carmeli \& Gefen, 2005), work family role (Akintayo, 2010), communication climate and job satisfaction (Trombetta \& Rogers, 1988).

It would appear there is a dearth of literature which examined the effect of joint consultation in improving workers' commitment in Nigeria. This is an important area, because there is need for organizations to understand the importance of giving employee voice through the use of Joint Consultation. This importance has been 
reiterated by Marchington (1992) when he reports that Joint Consultation helps reduce industrial action as it provides an opportunity for employees to express their views. Other studies have shown the effectiveness of Joint Consultation in improving work related behaviours (Fernie \& Metcalf, 1995; Dix \& Oxenbridge, 2003; Holland et al., 2009).

Most studies are based on Western Cultures (Parasuraman \& Jones, 2006; Marchington \& Armstrong, 2001; Pyman et al., 2009; Fernie \& Metcalf, 1995). There is little evidence that researchers have examined the effect of joint consultation as a form of employee voice on workers commitment in Nigeria Organizations. This research work is therefore carried out to fill the gap in the literature by examining the effect of joint consultation on worker's commitment in the Nigerian Banking Industry.

\section{Literature Review}

\subsection{Joint Consultation}

Joint consultation is a formal system of communication between the management of an organization and the employees' representatives used prior to taking decisions affecting the workforce, usually carried out by a joint consultative committee (Collins Dictionary, 2000). According to Armstrong (2003), joint consultation enables managers and employee representatives to meet on a regular basis in order to exchange views and utilize member's knowledge and expertise in dealing with matters of common interests that are not the subject of collective bargaining. Armstrong (2003) reports that for joint consultation to work well, it is necessary to first define, discuss and agree on its objectives. These objectives should be related to tangible and significant aspects of the job, the process of management, or the formulation of policies that affect the interests of employees. That consultation should take place before decisions are made. Management must believe in employees and involve them in decision making. The unions must also believe in participation as a genuine means of giving them voice and advancing the interests of their members, instead of using it as a way of getting more power.

It is believed (Marchington, 1992; Parasuraman \& Jones, 2006) that employers introduce joint consultation for the following reasons: to enhance efficiency by increasing the stock of ideas, which are available within the organisation because of the wider exposure of an issue or problem; to reduce industrial action as it provides an opportunity for employees to express their views; it leads to increased employee satisfaction due to the greater level of commitment that joint consultative committee brings. Researchers (Guest \& Peccei, 1998; Parasuraman \& Jones, 2006; Marchington \& Armstrong, 2001) have highlighted the usefulness of joint consultation in organisations. Guest and Peccei (1998) reports that joint consultation was highly favoured by companies at different stages in their progress towards a partnership arrangement with employee representatives in the area of policy making and strategic matters. In their study of a Malaysian firm, Parasuraman and Jones (2006) reported that Joint Consultative Committee is focused towards joint decision making on selected operational and strategic issues. It provides employees with bargaining power. Workers and unions actively engage in decision making, but only to a limited extent. Marchington and Armstrong (2001) are of the view that Joint consultative committee may be successful in most organisations because employers have shown their commitment to the unions and employee relations. Also in an environment characterized by hyper competition and change, there is need for management and employees/employee representatives to work together, rather than to work against each other. Emmott (2010) believe that joint consultation can have a positive effect on employee attitudes, reassuring employees that their interests are not being ignored when key decisions are taken. Joint consultation can enhance employee trust in management and in the credibility of management messages. It can also show respect and reinforce a belief in management's intention to behave fairly.

In their research Bates and Murphy (1981) see joint consultation as primarily concerned with 'information sharing' and not 'influence sharing'. They report the participants in their study see it as a method of communication, by which information can flow both to and from the bottom and top levels of the organization. This communication can and is used for propaganda purposes, such as canvassing support for management decisions or attempting to reduce the scope and influence of the unions. Joint consultation was also used by management to test employees' feelings on issues and as an early warning system for major grievances. There is a consistent assumption that the manager gains from the opportunity to hear the employees' comments on decisions and that change is more likely to be accepted if employees are, in some way, involved.

Bates and Murphy noted that Joint consultation continued to survive in the study organization partly because of the lack of consensus as to its function by organization members and partly as the result of what amounted to a conspiracy of vested interests. They concluded by asserting that joint consultation was a deterrent to employee's participation in organisations and hence does not promote employee voice. Pyman et al (2008) research on joint consultation in Australia revealed that there was a decline in the use of joint consultation for the period 2004 to 
2007, though it is still used as a form of employee voice. Employees believe that joint consultation does not represent their views and is being monopolized by management. With these diverse views regarding the use of joint consultation, this work examined workers commitment and its relationship with joint consultation as highlighted by other researchers. It is the author's contention that when employees are given voice with the use of joint consultation their commitment to the organization will increase.

\subsection{Workers Commitment}

The concept of commitment has received several critical reviews (Meyer and Allen, 1991; Mowday, Porter \& Steers 1982; Swailes, 2002; Argyle, 1989; Etzioni, 1975). Guest and Conway (1998, p. 21) posit that the key concern for organisations is how to capture and retain the commitment of employees. This is because positive organisational commitment is associated with higher motivation, higher performance and less likelihood of employees leaving the organisation.

Argyle (1989) proposed that commitment could be thought of in two ways: calculative and affective commitment. Calculative commitment according to him is an instrumental attachment to an organisation, while affective commitment is an emotional attachment to the organisation. Argyle's view of commitment corresponds with Rousseau (1989) and McNeil (1985) idea of transactional (calculative) and relational (affective) contract orientation. Mowday, Porter and Steers (1982, p. 26) define commitment as "the relative strength of an individual's identification with and involvement in a particular organisation characterised by strong acceptance or a belief in an organisation's goals and values; willingness to exert effort on behalf of the organisation; and a strong desire to maintain membership of the organisation." This definition has been criticized (Swailes 2000) for not carefully separating the motives for commitment from their effects. In particular, a desire to remain with an organisation can be seen as a consequence of commitment rather than as part of its definition. Mowday et al categorise commitment into two: attitudinal and behavioural commitment. They assert, "Attitudinal commitment focuses on the process by which people come to think about their relationship with the organization. In many ways it can be thought of as a mind set in which individuals consider the extent to which their own values and goals are congruent with those of the organisation. Behavioural commitment on the other hand, relates to the process by which individuals become locked into certain organizational and how they deal with this problem. Mowday et al (1979) developed the organisational commitment questionnaire, which is used to measure organisational commitment. Commitment is subdivided into three sub-concepts, forming two subsequent types of commitment. These are the employees desire to remain in an organisation (continuance commitment), willingness to exert effort on behalf of the organisation (affective), and belief in and acceptance of the values and goals of the organisation (attitudinal). This view closely mirrors Meyer and Allen's (1991) model of organisational commitment. The Organisational commitment questionnaire has been criticised (Singh \& Vinnicombe, 2000; Rousseau, 1989) as being too limited in the new era of downsizing and flexibility, where employees put in effort to help the organisation because they want to keep their jobs and not because of any attachment to the organisation. Also the OCQ fails to measure important features such as concern for quality, a sacrifice orientation and willingness to share information. Rousseau (1989) criticism of this view of commitment is based on the fact that commitment in this sense is too limited and broad. It does not address issues of reciprocity or obligation.

The most influential current model of measuring workers commitment to their organization is that of Meyer and Allen (1991). This is because several studies (Meyer \& Allen, 1991; Herscovitch \& Meyer 2002; Ko et al., 1997) have been conducted to test the applicability of the three-component model of organisational commitment. These studies provide strong evidence for the generalizability of Meyer and Allen's $(1991,1997)$ model of commitment. Meyer and Allen (1991) define workers commitment as "a psychological state that characterizes the employees' relationship with the organization which has implications for the decision to continue or discontinue membership in the organization." Organisational commitment, they suggest, comprises of three factors: Affective, normative and continuance.

Affective commitment is concerned with the individual's emotional attachment and identification with the organisation. Employees with affective commitment stay with the organisation because they want to.

Continuance commitment is more calculative. Employees with continuance commitment are aware of the cost associated with leaving the organisation and they stay with the organisation because they need to.

Normative commitment has to do with feelings of obligations employees have to continue with the organisation. McDonald and Makin (2000) posits that society's norms and a feeling that employees ought to remain with the organisation influence this commitment.

Meyer and Allen (1991) suggest that employees can experience all three forms of commitment to varying 
degrees and the strength of each is influenced by different factors. Affective commitment is influence by the extent to which employee's needs and expectations about the organisations are matched by their actual experience. Continuance commitment comprises of personal sacrifice associated with leaving and limited opportunities for other employment. While normative commitment is influenced by societal norms and culture. McDonald and Makin (2000) suggest that normative commitment is based on social exchange theory, whereby a person receiving a benefit is under a strong "normative" obligation to repay it in some way.

Meyer and Allen (1991) argue that workers commitment as a psychological state does not need to be restricted to value and goal congruence as described by Mowday et al (1982). They assert that organisational commitment reflects a desire, need, and obligation to maintain membership in the organisation. This view has found strong support from various researchers (Dunham et al., 1994; Hackett et al., 1994; McGee \& Ford, 1987). Lee et al (2001) found strong support for Meyer and Allen's conceptualisation of organisational commitment. Using data from Korean samples, they were able to construct internally consistent measures of each commitment component and report that it can be generalised in non-western cultures. Likewise Shore et al (1995) assert that those who are perceived to be more affectively committed are more likely to be seen to have high potential. They are then more likely to be given career development rewards than those with perceived high continuance commitment, who are seen to want to stay in the organisation because of their investment in "side bets" such as pension, accrued holidays and status, but who also may have no other options of employment. Studies (Aven et al., 1993; Meyer et al., 1990; Ahiauzu \& Asawo, 2009) suggest that committed workers contribute to the organisation in more positive ways than less committed workers. Therefore this study examined the effect of joint consultation on workers' commitment.

\subsection{Joint Consultation and Workers Commitment}

From the review of literature, researchers have shown how joint consultation acts as a channel for employee voice. Managers' use it to gain co-operation from employees in order to secure company survival and growth in an era of competitive pressures (Cregan \& Brown, 2010). Such forums allow management and employee representatives to meet and resolve problems amicably. Employee representatives are also given the opportunity to contribute in the decisions taken by management. This will lead to organisational commitment and job satisfaction of workers. Marchington (1992) report that joint consultation leads to positive organisational outcomes such as increased productivity, efficiency, better management and employee relationship. To buttress this fact, Muthuveloo and Rose (2005) posit that when employees have a favourable attitude to management, it will improve their motivation, which in turn will lead to higher organisation commitment. Joint consultation as a form of employee voice has been linked to organizational performance and high commitment of employees (Boxall \& Purcell, 2003). Empirical research also supports this view (Holland et al., 2009; Parasuraman \& Jones, 2006; Marchington \& Armstrong, 2001). We infer from the foregoing discussions that:

$\mathrm{Ho}_{1}$ : there is no significant association between joint consultation and employees' affective commitment.

$\mathrm{Ho}_{2}$ : there is no significant association between joint consultation and employees' continuance commitment.

$\mathrm{Ho}_{3}$ : there is no significant association between joint consultation and employees' normative commitment.

\section{Methods}

This study is a cross sectional survey. The population comprised senior and junior employees in the listed banks in the Nigeria Stock Exchange. The accessible population was all the employees in the bank's headquarters in the six state capital of the South-South zone of Nigeria. The population figure was sourced from the bank's nominal roll. A total of 5000 employees made up the total population. The sample size for this study was determined by using Krejcie and Morgan's (1970) table on sample size determination which was 357 employees. However when the copies of questionnaire were distributed, the completed and usable copies for the analysis was 315 , representing $88.24 \%$ of respondents who genuinely participated in the study. The instrument used for data collection was the questionnaire and in-depth interview. The questionnaire was divided into two sections. Section A comprised demographic information such as age, gender, length of stay in the organization and educational qualifications. Section B elicited respondent's views concerning the study variables. The questionnaire adopted the 5-point Likert Scale rating, where respondents were asked how strongly they agree or disagree with a statement or series of statement. The scale used for measuring joint consultation was adapted from the work of Holland et al (2009). Workers Commitment was measured using Allen and Meyer's (1990) Organizational Commitment Questionnaire (OCQ). The OCQ measured affective commitment, continuance commitment and normative commitment. Affective commitment had 9 items, while continuance and normative commitment had 8 items each. The variables that were employed for this study were sourced from existing literature and had been pre-tested and validated in previous studies (Holland et al., 2009; Allen \& Meyer, 1990; Meyer \& Allen, 1991; Herscovitch \& Meyer, 2002; 
Pittorino, 2008). The variables therefore had construct validity. Cronbach Alpha was used to test for reliability in our study. Cronbach alpha is commonly used in research to test internal reliability. Researchers, (Bryman and Bell, 2003; Nunally \& Berstein, 1994; Sekaran, 2003) consider an alpha level of 0.7 efficient. For test of reliability the following Cronbach Alpha Coefficient was obtained for our scales: Joint Consultation (0.767), Affective Commitment (0.771), Continuance Commitment (0.724), and Normative Commitment (0.708). All the variables had internal reliability.

\section{Data Analysis and Results}

Frequencies and percentages were used to classify the demographic data. The results from demographic data indicated that majority of the workers had been working for the bank between 1-3years which represents $47.94 \%$ of respondents, $24.8 \%$ of workers had been working between $4-5$ years, while employees who had worked between 4-8 years represented $3.2 \%$ of respondents and those with over 8years represented $7.6 \%$ of respondents. Males working in the banking industry were 168 representing $53.3 \%$ of respondents, while females made up the remaining $46.7 \%$ and were 147 in number. $47.3 \%$ of respondents were between the ages of $20-29,45.7 \%$ were between the ages of $30-39,6.7 \%$ were between the ages of $40-49$ and only one person was 50 and older. Respondents with Bachelor's degree were 157 in number representing 49.8\%, Diploma/Certificate 85 (27\%), Post Graduate Degree $66(21 \%)$ and West African Examination Certificate or its equivalent were 7 in number representing $2.2 \%$ of respondents. This indicates that most workers were highly educated in the banking industry in Nigeria.

Univariate Statistics was used to analyse each individual variable as shown in tables $1-5$.

Table 1. Descriptive statistics of joint consultation

\begin{tabular}{lllllllll}
\hline & JCS1 & JCS2 & JCS3 & JCS4 & JCS5 & JCS6 & JCS7 & JCS8 \\
\hline $\mathrm{N} \quad$ Valid & 315 & 315 & 315 & 315 & 315 & 315 & 315 & 315 \\
\multicolumn{1}{c}{ Missing } & 0 & 0 & 0 & 0 & 0 & 0 & 0 & 0 \\
Mean & 3.2857 & 2.1556 & 1.5905 & 2.7397 & 2.9492 & 2.7238 & 2.6381 & 2.6444 \\
Std. Deviation & .93121 & 1.31306 & 1.15952 & 1.03236 & 1.12469 & 1.24789 & 1.31229 & 1.26463 \\
Skewness & -1.503 & -.358 & .192 & -.895 & -1.130 & -.939 & -.891 & -.894 \\
td. Error of Skewness & .137 & .137 & .137 & .137 & .137 & .137 & .137 & .137 \\
Minimum & .00 & .00 & .00 & .00 & .00 & .00 & .00 & .00 \\
Maximum & 4.00 & 4.00 & 4.00 & 4.00 & 4.00 & 4.00 & 4.00 & 4.00 \\
\hline
\end{tabular}

Source: Spss Computation.

Table 2. Descriptive statistics of affective commitment

\begin{tabular}{llllllllll}
\hline & ACS1 & ACS2 & ACS3 & ACS4 & ACS5 & ACS6 & ACS7 & ACS8 & ACS9 \\
\hline $\mathrm{N} \quad$ Valid & 315 & 315 & 315 & 315 & 315 & 315 & 315 & 315 & 315 \\
\multicolumn{1}{c}{ Missing } & 0 & 0 & 0 & 0 & 0 & 0 & 0 & 0 & 0 \\
Mean & 1.8825 & 2.7841 & 2.5175 & 2.1048 & 1.6063 & 1.5810 & 2.3778 & 1.4921 & 1.6317 \\
Std. Deviation & 1.39683 & 1.04260 & 1.30732 & 1.27137 & 1.08726 & 1.10972 & 1.29679 & 1.09534 & 1.36760 \\
Skewness & .049 & -1.374 & -.852 & -.320 & .278 & .364 & -.809 & .364 & .214 \\
Std. Error of Skewness & .137 & .137 & .137 & .137 & .137 & .137 & .137 & .137 & .137 \\
Minimum & .00 & .00 & .00 & .00 & .00 & .00 & .00 & .00 & .00 \\
Maximum & 4.00 & 4.00 & 4.00 & 4.00 & 4.00 & 4.00 & 4.00 & 4.00 & 4.00 \\
\hline
\end{tabular}

Source: Spss Computation. 
Table 3. Descriptive statistics of continuance commitment

\begin{tabular}{lllllllll}
\hline & CCS1 & CCS2 & CCS3 & CCS4 & CCS5 & CCS6 & CCS7 & CCS8 \\
\hline $\mathrm{N} \quad$ Valid & 315 & 315 & 315 & 315 & 315 & 315 & 315 & 315 \\
\multicolumn{1}{c}{ Missing } & 0 & 0 & 0 & 0 & 0 & 0 & 0 & 0 \\
Mean & 2.1238 & 1.8571 & 2.3079 & 2.2349 & 2.1651 & 2.0857 & 2.1714 & 2.1937 \\
Std. Deviation & 1.26965 & 1.18989 & 1.26079 & 1.36682 & 1.32036 & 1.29512 & 1.31472 & 1.25833 \\
Skewness & -.103 & .062 & -.674 & -.567 & -.407 & -.178 & -.201 & -.206 \\
Std. Error of Skewness & .137 & .137 & .137 & .137 & .137 & .137 & .137 & .137 \\
Minimum & .00 & .00 & .00 & .00 & .00 & .00 & .00 & .00 \\
Maximum & 4.00 & 4.00 & 4.00 & 4.00 & 4.00 & 4.00 & 4.00 & 4.00 \\
\hline
\end{tabular}

Table 4. Descriptive statistics of normative commitment

\begin{tabular}{lllllllll}
\hline & NCS1 & NCS2 & NCS3 & NCS4 & NCS5 & NCS6 & NCS7 & NCS8 \\
\hline N Valid & 315 & 315 & 315 & 315 & 315 & 315 & 315 & 315 \\
\multicolumn{1}{c}{ Missing } & 0 & 0 & 0 & 0 & 0 & 0 & 0 & 0 \\
Mean & 2.2730 & 1.8190 & 2.3175 & 2.3111 & 1.8825 & 2.0952 & 1.9778 & 1.6476 \\
Std. Deviation & 1.37136 & 1.20599 & 1.28719 & 1.43157 & 1.22689 & 1.17178 & 1.31484 & 1.35426 \\
Skewness & -.398 & .352 & -.591 & .470 & .496 & .077 & .024 & .079 \\
Std. Error of Skewness & .137 & .137 & .137 & .137 & .137 & .137 & .137 & .137 \\
Minimum & .00 & .00 & .00 & .00 & .00 & .00 & .00 & .00 \\
Maximum & 4.00 & 4.00 & 4.00 & 12.00 & 4.00 & 4.00 & 4.00 & 4.00 \\
\hline
\end{tabular}

Table 5. Descriptive statistics of variables

\begin{tabular}{llllll}
\hline & $\mathrm{N}$ & Mean & Std. Deviation & Skewness & \\
\hline & Statistic & Statistic & Statistic & Statistic & Std. Error \\
JCS & 315 & 2.5909 & .72786 & -.702 & .137 \\
ACS & 315 & 1.9975 & .64236 & .364 & .137 \\
CCS & 315 & 2.1425 & .75092 & .028 & .137 \\
NCS & 315 & 2.0405 & .74410 & .591 & .137 \\
ValidN (listwise) & 315 & & & & \\
\hline
\end{tabular}

The overall mean score $(\mathrm{x})$ for Joint Consultation $(\mathrm{JCS})=2.59$, Affective Commitment $(\mathrm{ACS})=1.99$, Continuance Commitment $(\mathrm{CCS})=2.14$, and Normative Commitment $(\mathrm{NCS})=2.04$.

For the bivariate analysis the Spearman Rank Order Correlation Coefficient is calculated using SPSS to establish the association between Joint Consultation and Workers Commitment. To test the hypotheses, the following guidelines were used to accept or reject the null hypotheses: when the statistical test of significance ( $\mathrm{P}$-value) is less than 0.05 i.e., $\mathrm{P}<0.05$, the null hypothesis was rejected, when $\mathrm{P}>0.05$, the null hypothesis was accepted. This is in line with Kathari's (2006) decision rule. The confidence interval was set at the 0.05 (two tailed) level of significance to test the statistical significance of the data in this study. Table 6 presents the result of the association between Joint Consultation (JCS) and Workers Commitment-Affective Commitment (ACS), Continuance Commitment (CCS), and Normative Commitment (NCS).

Table 6. Association between joint consultation and worker's commitment

\begin{tabular}{llllll}
\hline & & JCS & ACS & CCS & NCS \\
\hline \multirow{2}{*}{ Spearman's rho } & \multirow{2}{*}{ JCS } & Correlation Coefficient & 1.000 & $.111(*)$ & .029 \\
& & Sig. (2-tailed) &. & .050 & .608 \\
\hline
\end{tabular}

* Correlation is significant at the 0.05 level (2-tailed).

** Correlation is significant at the 0.01 level (2-tailed). 
The result of the correlation in table 6 shows that for hypothesis one the coefficient $r=0.111^{*}$ and $p=0.050$, therefore the first null hypothesis is rejected. There is a significant positive association between joint consultation and affective commitment at the 0.05 level of significance.

The result in table 6 shows that for hypothesis two $r=0.029, p=0.608$. Therefore the second null hypothesis is accepted. There is no significant association between joint consultation and continuance commitment.

The result in table 6 shows that hypothesis three $r=0.032, p=0.568$. Therefore the third Null hypothesis is accepted. There is no significant association between Joint Consultation and Normative Commitment.

Our findings indicate that:

- There is a significant positive association between Joint Consultation and Affective Commitment.

- There is no significant association between Joint Consultation and Continuance Commitment.

- There is no significant association between Joint Consultation and Normative Commitment.

This result is consistent with the in-depth interview conducted. Notes were taken in recording participant's responses. The questions were based on the survey instrument and elicited information about bankers views of the use of joint consultation and how it affects their commitment to their organization. Two participants from the six states were selected and a total of twelve banking personnel were interviewed.

Respondents reported that there is a committee of management and employees who meet on a regular basis. Sometimes these committees meet twice monthly, once monthly or when there are issues to be resolved. Members of the Joint Consultative Committee are usually elected by fellow employees. Such members chosen are the ones employees feel are quite vocal and have no fear in speaking up for the truth. Hence workers have trust in such persons. Some participants report that the members are selected by top management. Those in the good books of management and seen as "managers boys". To such persons the Joint Consultative Committee was seen to be window dressing, because the views of management always hold sway in such discussions. All participants agree that union membership is on the decline in the banking sector; hence they do not have much influence in decision making. The Joint Consultative Committees are at liberty to discuss issues such as company objectives and strategic plans. They also discuss health, safety and working conditions. Though on the issue of dispute settlements and disciplinary procedures, interviewees comment that such matters are strictly controlled by management and they use their powers to resolve any issues arising therein. The committees have powers to make decisions over matters they were empowered to discuss. As one participants said "since management allows the decision of the joint consultative committee to stand, it gives us in the bank a feeling of commitment, because our representatives can make decisions with them (top management) and they implement it". This makes workers feel that they play an important role in decision making in the bank.

From the above statements, it is observed that employees are affectively commitment to their banks, since they believe management cares about their views and positively encourage their input in decision making.

\section{Discussion of Findings}

It has been found in this study that Joint Consultation as a form of Employee Voice exists in the Nigerian Banking Industry. This influences employees to be affectively committed to their organizations. Employees identify with and are emotionally attached to their banks because of the presence of Joint Consultation. According to Marchington (1992) Joint consultation enhances efficiency by increasing the stock of ideas which are available within an organization because of the wider exposure of an issue or problem. Joint consultation reduces industrial action as it provides an opportunity for employees to express their views. The low incidence of strike actions by Nigeria Bankers may be as a result of the presence of Joint Consultation. Parasuraman and Jones, (2006) believe that joint consultation leads to increased employee satisfaction due to the greater level of commitment that joint consultative committee brings.

These statements are in line with the research findings. Employees' believe that management involves them in decision making because they have trust and believe in them. That is why decisions made by joint consultative committees are implemented by management.

The findings run contrary to that proposed by Bates and Murphy, (1981) and Pyman et al., (2008) that joint consultation was a deterrent to employee voice and is being monopolized by management. Bates and Murphy's study was carried out in a single organization; hence it was a case study. They used observation and interviews in their methodology to arrive at their findings.

In this study, a full scale scientific investigation was utilized. It was found that joint consultation enables employee representatives have opportunity to contribute to the decisions taken by management. This has led to 
employees being emotionally attached to the organization. Meyer and Allen (1997) explained that affective commitment is stronger than continuance or normative commitment because employees who are affectively committed will be more motivated to higher levels of performance and make more meaningful contributions to enable organizations achieve their goals.

These findings support other researchers (Muthuveloo \& Rose, 2005; Machington, 1992; Boxall \& Purcell, 2003) contention that joint consultation is linked to organizational performance and high commitment of employees; when employees have a favourable attitude to management it will improve their motivation leading to higher organizational commitment.

Employees in the banking industry in Nigeria were found to be affectively committed to their firms; it means they have a sense of belonging and identification that increases their involvement in the organization's activities. They are willing to pursue the organizations goals and remain with the organization because they want to out of love (Meyer \& Allen 1991). This is in line with the Social Exchange Theory which implies a give and take relationship. As management gives employee voice through the use of joint consultation, employees in turn are committed to the organization and put in their best to aid the organization achieve its set objectives.

In the banking industry in Nigeria, organizational members did not exhibit continuance and normative commitment by the presence of joint consultation as a form of employee voice. The results of this study revealed that employees stay with the organization not because of the costs that they associate with leaving the organization nor because of feelings of obligations to stay. They are truly attached to the organization. Meyer and Allen (1991) point out that the willingness of employees to contribute to organizational effectiveness is influenced by the form of commitment they experience. That an affectively committed employee would be more likely to exert effort on behalf of the organization as he or she has a desire to maintain employment in the organization as compared to an employee who needs to stay because of the cost associated with leaving (continuance commitment), or one who stays because of moral obligation or societal expectations (normative commitment).

The use of Joint Consultation as a form of Employee Voice in the Banking Industry in Nigeria has a significant positive effect on workers affective commitment to their organization.

\section{Conclusions and Implication}

The conclusions drawn from this study are that:

(i) The use of Joint Consultation as a form of Employee Voice in the Banking Industry in Nigeria makes employees to be emotionally attached to their organization.

(ii) The use of Joint Consultation as a form of Employee Voice in the Banking Industry in Nigeria makes employees stay with the organization because they want to and not because of the cost associated with leaving the bank.

(iii) The use of Joint Consultation as a form of Employee Voice in the Banking Industry in Nigeria made employees stay with their banks because they want to and not because of feelings of moral obligation to do so.

This study has theoretical implications as it confirms the findings of other studies. In the banking industry in Nigeria, the use of Joint Consultation positively affects workers affective commitment. Workers are emotionally attached to their organizations when management meets with their representatives to discuss issues concerning them. The fact that decisions arrived at from such meetings are implemented makes them feel the organization cares for them and are interested in their views. This supports Marchington and Armstrong (2001) findings that joint consultative committee are successful in most organizations because employers have shown their commitment to the organization. Our findings are also in line with Emmott (2010) contention that joint consultation has a positive effect on employee's attitudes, reassuring them that their interests are not being ignored when key decisions are taken. This enhances employees trust in management.

This study has shown that the use of joint consultation as a form of employee voice contributes to a high level of workers affective commitment. Managers should therefore be cognizant of the fact that when they involve employees' representatives in decision making in the organization, employees' will be happy and hence their affective commitment will increase. Affective commitment according to Gurses and Demiray (2009) is the best form of commitment because employees reflect positive attitudes towards the job and are ready to exert extra effort on behalf of the organization.

\section{References}

Ahiauzu, A., \& Asawo, S. P. (2009). Altruistic Love Culture and Workers' Commitment in the Nigerian 
Manufacturing Industry. A study in Workplace Spirituality. In Sigue, S. (Ed.), Repositioning African Business and Development for the 21st Century (pp. 351-358). A paper Presented on the Proceedings of the 10th Annual Conference IAABD.

Ahiauzu, A., \& Asawo, S. P. (2012). Impact of Clear and Compelling Vision on Worker's Commitment in Nigerian Organizations: An Examination of Workplace spirituality. Journal of Leadership, Accountability and Ethics, 9(6), 113-124.

Akintayo, D. I. (2010). Work Family Role conflict and Organizational Commitment among Industrial Workers in Nigeria. Journal of Psychology and Counseling, 2(1), 1-8

Allen, N. J., \& Meyer, J. P. (1990). The Measurement and Antecedents of Affective, Continuance and Normative Commitment to the Organisation. Journal of Occupational Psychology, 63, 1-18

Angle, H. L., \& Perry, J. L. (1981). An empirical assessment of organizational commitment and effectiveness. Administrative Science Quarterly, 26, 1-14. http://dx.doi.org/10.2307/2392596

Ardrey, W. J., Pecotich, A. J., \& Ungar, E. (2001). Structure, Commitment and Strategic Action for Asian Transitional Nations Financial Systems in Crisis. International Journal of Bank Marketing, 19(1), 18-36. http://dx.doi.org/10.1108/02652320110366490

Argyle, M. (1989). The Social Psychology of Work London. Penguin PMCid: PMC303720.

Armstrong, M. (2003). A Handbook of Human Resource Management Practices (9th ed.). London: Kogan Page Limited.

Aven, F. F., Parker, B., \& McEvoy, G. (1993). Gender and Attitudinal Commitment in Organisations A Meta-Analysis. Journal of Business Research, 26, 65-73. http://dx.doi.org/10.1016/0148-2963(93)90043-O

Bate, S. P., \& Murphy, A. J. (1981). Can Joint Consultation become Employee Participation? Journal of Management Studies, 18(4), 27-49. http://dx.doi.org/10.1111/j.1467-6486.1981.tb00052.x

Boxall, P., \& Purcell, J. (2003). Strategy and Human Resource Management Palgrave Macmillan. Basingstoke

Bryman, A., \& Bell, E. (2007). Business Research Methods (2nd ed.). UK, Oxford: University Press.

Cregan, C., \& Brown, M. (2010). The Influence of Union Membership Status on Workers willingness to participate in Joint Consultation. Human Relations, 63(3), 331-348. http://dx.doi.org/10.1177/0018726709348934

Dix, G., \& Oxenbridge, S. (2003). Information and Consultation at work: from challenges to good practice. Research Paper ACAS Research and Evaluation Section. Retrieved from http://www.acas.org.uk

Dunham, R. B., Grube, J. A., \& Castaneda, M. B. (1994). Organisational Commitment: The Utility of an Integrative Definition. Journal of Applied Psychology, 79(3) 370-380. http://dx.doi.org/10.1037/0021-9010.79.3.370

Farndale, E., Ruiten, J. V., Kelliher, C., \& Hope-Hailey, V. (2011). The Influence of Perceived Employee Voice on Organizational Commitment: An Exchange Perspective. Human Resource Management, 50(1), 113-129. http://dx.doi.org/10.1002/hrm.20404

Fernie, S., \& Metcalf, D. (1995). Participation, Contingent pay, representation and workplace performance: evidence from Great Britain. British Journal of Industrial Relations, 33, 379-415. http://dx.doi.org/10.1111/j.1467-8543.1995.tb00445.x

Gbadamosi, G. (2003). HRM and the Commitment Rhetoric: Challenges for Africa. Management Decision, 41(3), 274-280. http://dx.doi.org/10.1108/00251740310475218

Guest, D. E., \& Conway, N. (1998). Fairness at Work and the Psychological Contract Institute of Personnel and Development London.

Gurses, N., \& Demiray, E. (2009). Organizational commitment of employees of T.V production center (educational television). The Turkish Online Journal of Educational Technology, 8(1).

Hackett, R. D., Bycio, P., \& Hausdorf, P. A. (1994). Three-Component Model of Organisational Commitment. Journal of Applied Psychology, 79(1), 15-23

Herzcovitch, L., \& Meyer, J. P. (2002). Commitment to Organizational Change: Extension of a Three-Component Model. Journal of Applied Psychology, 87(3), 474-487. http://dx.doi.org/10.1037/0021-9010.87.3.474 
Holland, P., Pyman, A., Cooper, B. K., \& Teicher, J. (2009). The Development of Alternative Voice Mechanisms in Australia: The Case of Joint Consultation. Economic and Industrial Democracy, 30(1), 67-92. http://dx.doi.org/10.1177/0143831X08099434

Jaja, S. A., \& Okpu, T. (2013). Internal Attitude Survey and Workers Commitment in Nigerian Banking Industry. Research Journal of Finance and Accounting, 4(19), 94-102.

Jaja, S. A., \& Okpu, T. (2013). Suggestion Scheme and Workers Commitment in Nigerian Banking Industry. The International Journal of Engineering and Science, 2(11), 43-51.

Kimball, L. S., \& Nink, C. E. (2006). How to improve Employee Motivation, Commitment, Productivity, Well-Being and Safety. Corrections Today Magazine, 68(3), 66-69.

Ko, J. W., Price, J. L., \& Mueller, C. W. (1997). Assessment of Meyer and Allen's three-component model of organizational commitment in South Korea. Journal of Applied Psychology, 82, 961-973.

Kothari, C. R. (2006). Research Methodology: Methods and Techniques (2nd ed.). New Age International Publishers, New Delhi.

Krejcie, R. V., \& Morgan, D. W. (1970). Determining Sample Size for research activities Educational and Psychological Measurement.

Lee, K., Allen, N. J., \& Meyer, J. P. (2001). The Three-Component Model of Organisational Commitment, an Application to South Korea. Applied Psychology An International Review, 50(4), 596-614. http://dx.doi.org/10.1111/1464-0597.00075

Marchington, M. (1992). Surveying the practice of Joint Consultation in Australia. The Journal of Industrial Relations, 34, 530-549. http://dx.doi.org/10.1177/002218569203400402

Marchington, M. (1992). The Practice of Joint Consultation in Australia-A preliminary Analysis of the Awirs Data Acirrt. Working Paper, no. 21.

Marchington, M., \& Armstrong, R. (2001). The Nature of the New Joint Consultation. Industrial Relations Journal., 158-171.

McDonald, D. J., \& Makin, P. J. (2000). The Psychological Contract, Organisational Commitment and Job Satisfaction of Temporary Staff. Leadership and Organisational Development Journal., 21(2), 84-91. http://dx.doi.org/10.1108/01437730010318174

McGee, G. W., \& Ford, R. C. (1987). Two (or More?) Dimensions of Organizational commitment. Re-examination of the Affective and Continuance Commitment Scales. Journal of Applied Psychology, 72(4), 638-642. http://dx.doi.org/10.1037/0021-9010.72.4.638

McNeil, I. R. (1985). Relational Contract: What we do and do not know. Winconsin Law Review, 483-525.

Meyer, J. P., \& Allen, N. J. (1991). A Three-Component Conceptualisation of Organisational Commitment. Human Resources Management Review, 1(1), 61-89.

Meyer, J. P., \& Allen, N. J. (1997). Commitment in the Workplace Theory. Research and Application Sage Publications.

Meyer, J. P., Allen, N. J., \& Smith, C. A. (1993). Commitment to Organisations and Occupations Extension and Test of a Three-Component Conceptualization. Journal of Applied Psychology, 78(4), 538-551. http://dx.doi.org/10.1037/0021-9010.78.4.538

Mowday, R. T., Porter, L. W., \& Steers, R. M. (1979). The measurement of Organisational Commitment. Journal of Vocational Behaviour, 14, 224-247. http://dx.doi.org/10.1016/0001-8791(79)90072-1

Mowday, R. T., Porter, L. W., \& Steers, R. M. (1982). Employee Organization Linkages: The Psychology of Commitment, Absenteeism and Turnover. New York: Academy Press.

Muthuveloo, R., \& Rose, R. C. (2005). Typology of Organizational Commitment. American Journal of Applied Sciences, 2(6), 1078-1081. http://dx.doi.org/10.3844/ajassp.2005.1078.1081

Nunnally, J. C., \& Bernstein, I. H. (1994). Psychometric Theory. New York: McGraw-Hill.

Nwachukwu, C. C. (2006). Management Theory and Practice. Onitsha: Africana First Publishers.

Ogba, I. (2008). Commitment in the Workplace: The Impact of Income and age on Employee Commitment in Nigerian Banking Sector. Management Research News, 31(11) 867-878. http://dx.doi.org/10.1108/01409170810913051 
Okpara, J. O. (2004). Job Satisfaction and Organizational Commitment: Are there differences between American and Nigerian Managers employed in the US MNCs in Nigeria? A seminar paper presented at the Academy of Business and Administrative Sciences (ABAS) International Conference in Montreux, Switzerland.

Oladejo, M. A., Akinpelu, S. O., Fagunwa, A. O., \& Morakinyo, A. R. (2011). Job Related Factors, Leadership, Motivation and Career Commitment in a Nigerian College of Education. Pakistan Journal of Business and Economic Review, 1(1), 41-58.

Omolayo, B., \& Owolabi, A. B. (2007). Monetary Rewards: A Predictor of Employee's Commitment to Medium Scale Organizations in Nigeria. Bangladesh E-Journal of Sociology, 4(1), 42-48.

Parasuraman, B., \& Jones, M. L. (2006). Joint Consultation, University of Wollongong. Retrieved from http//ro.uow.edu.au/commpapers/45

Pittorino, L. A. (2009). The Relationship between Culture, Commitment, and Performance in a South African Electricity Utility.

Pyman, A., Holland, P., Cooper, B., \& Teicher, J. (2009). The Contours of Joint Consultation in Australia: Updating the Empirical Evidence. In International Industrial Relations Association 15th World Congress.

Rousseau, D. M. (1989). Psychological and Implied Contracts in Organisations. Employee Rights and Responsibility Journal., 2, 121-139. http://dx.doi.org/10.1007/BF01384942

Salami, S. O. (2008). Demographic and Psychological Factors Predicting Organizational Commitment among Industrial Workers. Anthropologist, 10(1), 31-38.

Sekaran, U. (2003). Research Methods for Business. New York: John Wiley and Sons.

Shore, L. M., Barksdale, K., \& Shore, T. H. (1995). Managerial perceptions of employee commitment to the organization. Academy of Management Journal., 38, 1593-1615. http://dx.doi.org/10.2307/256845

Sullivan, T. J. (2001). Methods of Social Research Harcourt College Publishers Orlando.

Swailes, S. (2002). Organizational Commitment: a critique of the Construct and Measures. International Journal of Management Reviews, 4(2), 155-178. http://dx.doi.org/10.1111/1468-2370.00082

Trombetta, J. J., \& Rogers, D. P. (1988). Communication Climate, Job Satisfaction and Organizational Commitment: The Effects of Information Adequacy, Communication Openness and Decision Participation. Management Communication Quarterly, 1(4), 494-514. http://dx.doi.org/10.1177/0893318988001004003

Zabid, M., Rashid, A., Sambasivan, M., \& Johari, J. (2003). The Influence of Corporate Culture and Organizational Commitment on Performance. Journal of Management Development, 22(8), 708-728. http://dx.doi.org/10.1108/02621710310487873

\section{Copyrights}

Copyright for this article is retained by the author(s), with first publication rights granted to the journal.

This is an open-access article distributed under the terms and conditions of the Creative Commons Attribution license (http://creativecommons.org/licenses/by/3.0/). 